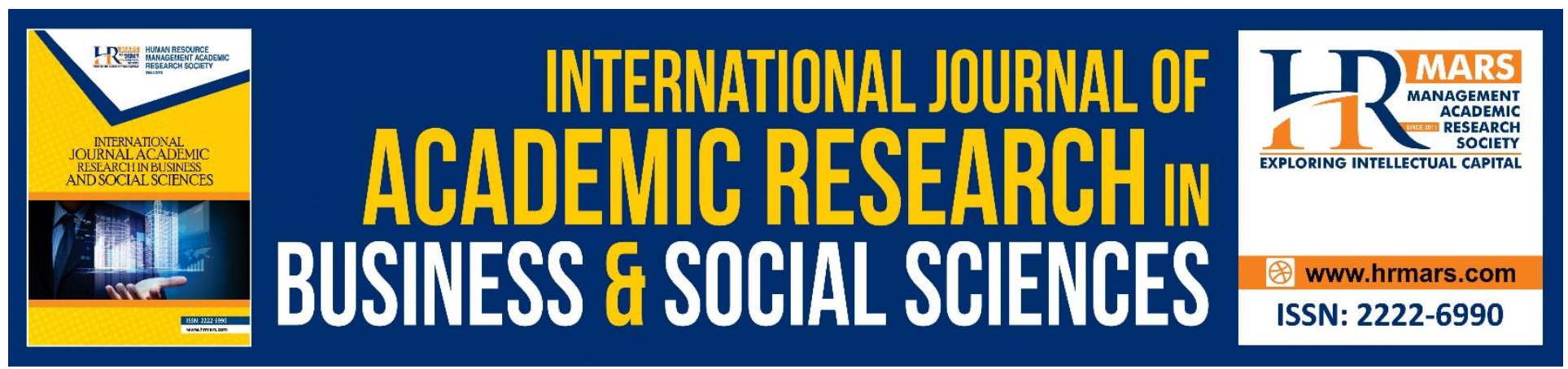

\title{
Balkan Bilingual Fairy Tales and Educational Activities
}

\author{
Konstantinos Tsoumitas, Petroula Ntonou, Ifigeneia Vamvakidou
}

To Link this Article: http://dx.doi.org/10.6007/IJARBSS/v9-i6/5984

DOI: 10.6007/IJARBSS/v9-i6/5984

Received: 12 April 2019, Revised: 24 May 2019, Accepted: 08 June 2019

Published Online: 28 June 2019

In-Text Citation: (Tsoumitas, Ntonou, \& Vamvakidou, 2019)

To Cite this Article: Tsoumitas, K., Ntonou, P., \& Vamvakidou, I. (2019). Balkan Bilingual Fairy Tales and Educational Activities. International Journal of Academic Research in Business and Social Sciences, 9(6), 707717.

Copyright: (C) 2019 The Author(s)

Published by Human Resource Management Academic Research Society (www.hrmars.com)

This article is published under the Creative Commons Attribution (CC BY 4.0) license. Anyone may reproduce, distribute, translate and create derivative works of this article (for both commercial and non-commercial purposes), subject to full attribution to the original publication and authors. The full terms of this license may be seen at: http://creativecommons.org/licences/by/4.0/legalcode

\section{Vol. 9, No. 6, 2019, Pg. 707 - 717}

Full Terms \& Conditions of access and use can be found at http://hrmars.com/index.php/pages/detail/publication-ethics 


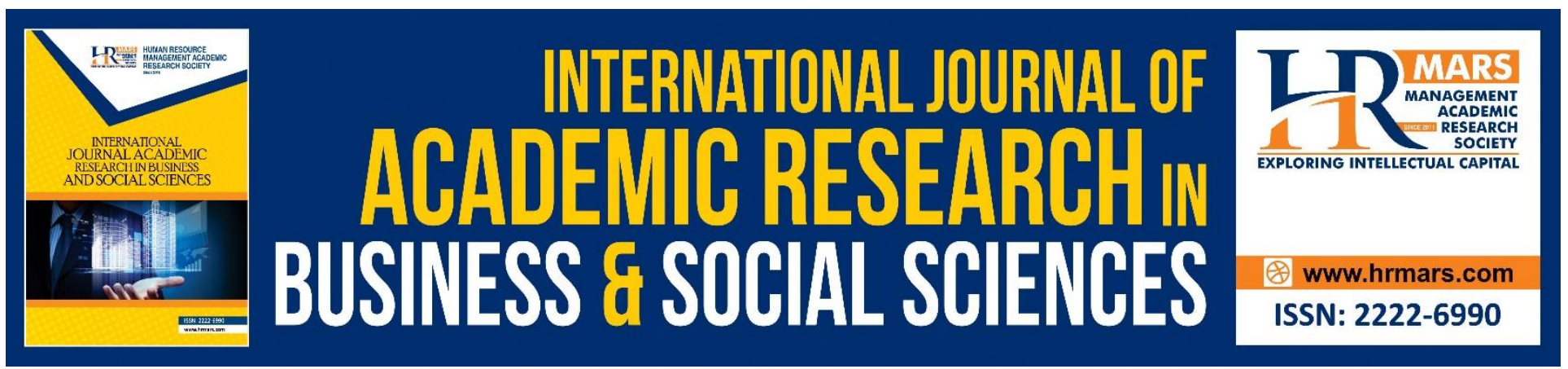

\title{
Balkan Bilingual Fairy Tales and Educational Activities
}

\author{
Konstantinos Tsoumitas, Petroula Ntonou, Ifigeneia Vamvakidou \\ Pedagogic School Department of Early Childhood Education University of Western Macedonia \\ Greece. \\ Email: kostask271@gmail.com, petrantonou90@gmail.com, ibambak@uowm.gr
}

\begin{abstract}
The geographic identification of the research concerns the Balkan countries. In particular, fairy tales were documented in local research in Florinas' borders area. The language material we present refers to Balkan languages. According to the linguists (Ivan Colovic, 2003; Paul-Louis Thomas, 2002-2003), the Serbo-Croatian language is defined as a polycentric common language, a language spoken by many peoples in different states, with recognizable linguistic variants. In linguistics the Balkan language link or Balkansprachbund refers to the name given to similarities in the grammar, syntax, vocabulary and phonology of the Balkan languages, although belonging to different branches of the Indo-European language family, such as Greek, Latin, Albanian, and Slavic languages.

Methodologically, we attempt the semiotics study of translation as an approach called translation semiotics: following Tzvetan Todorov, narrative is defined as a disturbance of balance, while as a myth the material of the story, which is narrated by a text.

Thus, as researchers and as readers we take on the techniques of narration, plotting and myth. The aim is to highlight the common and different patterns in the Balkan fairy tales, resulting in the translation material itself as new narratives.
\end{abstract}

Keywords: Borders, Narratives, Fairy Tales, Semiotic Translation

\section{Introduction}

Aspects of bilingual education, cross-curricular teaching, content-based teaching and others are now often seen as parts of a wider term-Content and Language Integrated Learning (CLIL). The term CLIL mainly means teaching other school subjects through L2, usually English. With young learners in a primary school context, both language teachers and class/subject teachers can benefit from implementing aspects of CLIL across the curriculum and integrating non-linguistic abilities into language learning (Darn, 2009).

Cross-curricular approaches, intercultural considerations, the learning of languages following content-based teaching, materials development for the new curricula and methods, as well as the contribution of ICT to the redirection of education constitute 
INTERNATIONAL JOURNAL OF ACADEMIC RESEARCH IN BUSINESS AND SOCIAL SCIENCES Vol. 9, No. 6, June, 2019, E-ISSN: 2222-6990 @ 2019 HRMARS

areas of current research in Europe and elsewhere. However, with the central focus on Greece's educational system, the challenging new ideas enlisted in Psaltou-Joycey, Agathopoulou and Mattheoudakis (2014) work being implemented by enthusiastic academics and dedicated practitioners, aspire to add useful insights into the relevant issues and promote ideas and practices worthy of being further Cross-Curricular Approaches to Language Education investigated.

Multilingualism has been defined as "the ability of societies, institutions, groups and individuals to engage, on a regular basis, with more than one language in their day-to-day lives" (European Commission, 2007, p. 6).

This is a broad definition which includes various levels of proficiency and communicative abilities in the languages used by a multilingual individual (Cenoz, 2009).

In this area, a selection criterion for on-site research and the specific mythological material collection is the geographic identification of the Balkan border with research questions about the similarities and differences in the narrative patterns. Besides the national populations as Greeks, Albanians, Bulgarians and Fyrom, Roma and Vlachs are also involved in this research as migratory populations and act as a cultural channel among the populations in borders (Katsanis \& Dinas, 1990), (Tsotsos, 1996). After the landmark year 1769, when Moschopolis suffered its first massive collapse, the Vlachs launched their best documented diaspora, from the south northwards. Groups large and small left their ancestral villages along the spine of the Pindos Mountains and moved out into the Balkans and even beyond. Inundating the wider geographical region of Macedonia, they established new settlements in the highlands and colonies in the developing towns. They reached as far as the Rodopi and Balkan Mountains and towns in Bulgaria; they established colonies in towns in Kosovo and Serbia they crossed the Danube and the Sava to swell the Greek Orthodox communities in the Habsburg Empire and the Danubian Principalities. This account and record of the massive Vlach diaspora clearly shows that Greece itself is the indisputable 'metropolis' of the Vlachs (Koukoudis, 2003).

The issue of the name of the Former Yugoslav Republic of Macedonia is not just a dispute over historical facts or symbols. It concerns the conduct of a UN member state, the Former Yugoslav Republic of Macedonia, which contravenes the fundamental principles of international law and order; specifically, respect for good neighborly relations, sovereignty and territorial integrity (www.mfa.gr). In the field of contemporary border studies, there is tendency at times to overlook or minimize the changeable, dynamic context of the existence of borders, and just accepting borders as a given. Thus, in researching the history of borders in globalization, it is necessary to "shake this idea up". We see now, in many parts of the world, an intense political interest in borders. There are calls for protection of borders, intensified border controls, and new walls to be built. At the same time there are political, capitalist and academic movements talking of global connections in terms of networks and transnational flows that appear to make political borders redundant.

The research field of Critical Heritage Studies - which sets out to enquire, analyze and understand how the past is appropriated, valued and used in the present - is now faced with an important challenge. The debate is about: How shall we, as heritage researchers and heritage officials, navigate in this border-focused political terrain? Is there need for radical reinvention of our 
INTERNATIONAL JOURNAL OF ACADEMIC RESEARCH IN BUSINESS AND SOCIAL SCIENCES

Vol. 9, No. 6, June, 2019, E-ISSN: 2222-6990 @ 2019 HRMARS

traditional connections between heritage and borders? What can we learn from historical and contemporary examples of the interplay between heritage and borders?

How do we bring important theoretical concepts into practical use, in critical research and in practical heritage work?

\section{Theoretical and Methodological Models}

Umberto Eco's theory of textual cooperation gives the reader an essential role in the process of making meaning. The text creates a Model Reader capable of actualizing the various meaningcontents in order to decode the possible worlds of the narrative. This reader fills in the many gaps in the text, which is never completely explicit, using anything from simple linguistic inference to a more complex deductive reasoning that applies to the entire narrative. The theory of the Model Reader is based on the concept of unlimited semiosis developed by S. Peirce: "The interpretant of a sign becomes in turn a sign, and so on ad infinitum" (Peirce, 1931: 35-6), (see the chapter on Peirce's Semiotics). The text is a fabric woven from signs. It is open and interpretable, but it must be viewed as a coherent whole. The text is essentially "a lazy machine that demands the bold cooperation of the reader to fill in a whole series of gaps" of unsaid or already said missing elements (Eco, 1985: 29) its coherence, a text may reduce the possibility of arriving at certain interpretations. The reader - or receiver - must exercise semiotic judgment, meaning that "in order to 'understand' the meaning of a text, especially if it is indirect, the receiver has to apply processes of interpretive cooperation" (Eco, 1988:71). In linguistic philosophy, the theory of possible worlds was originally developed in order to demonstrate the formal properties of systems of modal logic, which examine the logical relationships between utterances containing operators such as "necessity" and "possibility". A text is therefore open: All interpretations of it are potentially unlimited, but not every act of interpretation has a happy end. By interpretation we mean "the semantic actualization of everything that the text means, as a strategy, with the cooperation of its Model Reader" (Eco, 1985 :237).

Plot is the way a myth is presented. According to Tomashevsky, (1931) plot is the way the reader learned about the myth. Within the narrative plot there are smaller indivisible narrative units, which in narrative are called motifs or themes. This is a loan term from the music, where in it is the core, which gives an energy to a story, puts it and goes ahead (then we are talking about dynamic motifs) as opposed to the static motifs that fasten a story, narrative texts are the descriptions we meet. Here, in relation to work and its subject, and on account of the narrative pattern, we might perhaps call it the field of detection of the research material. The leximetry (which is the count of the essentials and adjectives) is a tool for the analysis of the research material and will be carried out within the field of grammar and syntax of the language of the mythological and social/cultural signifiers. Todorov (1969), supports what the Russian formalists have found as the existence of a crude fable and a material that under some circumstances is shaped in narrative text (suzet). It is argued that fable + suzet = make the history (the story) by which the writer becomes a transmitter. Readers are the receivers who will take on narrative text, which is nothing but a message. The leximetric analysis of localized signatures at the level of nouns and adjectives that exist within them and their quantitative concentration-evaluation in the end will show how certain literary choices at the lexicon level construct specific meanings that are directly related to the author's or to the nations' mythological world 


\section{Analysis}

The researching material comes from local historical research in the Balkans where we were travelling and were asking from the grandmothers in the small villages their most famous stories. Especially from the village (Aetos, Florina), in western Macedonia we collected the following:

- $\quad$ Fairy tale (1), "The student is better than the teacher". Title analysis: Anthropocentric model, pronounced, affirmative, declarative, hyphenated, comparative phrase. Grammatical analysis: two nouns, males in singular compared to each other. Scenario: A child using his mind manages to trick the teacher who is represented as a devil in order to secure a better future for him and his family. Symbols and code values: The Immaculate Family. The Devil, the smart young, the transformations.

- Fairy Tale (2), "Kyliáftses" (meaning lazy, used as the main name). Title analysis: Anthropocentric model, pronounced, affirmative, hyphenated phrase. Grammatical analysis: a noun, male in singular, main name. Scenario: A child who does not work in the mood, when needed, shows his real potential, proving that the mind prevails in the physical power. Symbols and images: The young man who did not consider him laborious, smart, beautiful, shows his value at the right time. The extermination of the monster.

- Fairy Tale (3), "The snake". Title analysis: animal model, pronounced, affirmative, declarative, hyphenated phrase. Grammatical analysis: a noun, in a negative signifier. Scenario: $A$ shepherd saves a snake, but this is about a very serious family adventure. Symbols and images: The snake, the animals with human gender, the unworthy husband.

Especially from the village (Сандански, София) in Bulgaria we collected the following:

- $\quad$ Fairy Tale (4), "The language of the animals, (Езиkътна ж ивотните)". Title analysis: animal model, affirmative, metaphorical phrase. Grammatical analysis: female noun of general origin. Scenario: A shepherd saves a snake, but this is about a very serious family adventure. Symbols and images: The snake, the understanding the language of the animals, the unworthy husband.

- $\quad$ Fairy Tale (5), "The bird of fire, (жар птица)". Title analysis: animal model, affirmative, metaphorical phrase. Grammatical analysis: a noun, in a negative signifier and general rating. Scenario: The younger son manages to catch the bird of fire, who is actually a beautiful girl. But curiosity led him to disobey his ban, putting his wife to death. For the sake of her wits, they are saved. Symbols and images: The three brothers, the apple tree, the girl with supernatural powers, the bantest (the seventh room), the dragon, the savior wife.

- $\quad$ Fairy tale (6), "The donkey and the horse, (Магаре и кон)". Title analysis: animal model, pronounced, affirmative, declarative, hyphenated phrase. Grammatical analysis: two nouns, in a male signifier. Scenario: The donkey, although disguised as a horse, is betrayed by its spite. Symbols and images: The horse-donkey dipole.

- $\quad$ Fairy tale (7), "After seeing what you ask? (Като вижgаш не питай)" .

Title analysis: anthropocentric model, a verbal phrase with questionnaire. Grammatical analysis: active verbs in binary, questionnaire. Scenario: A very clever Petros responds appropriately to an unnecessary question. Symbols and images: Folk wisdom, a very clever Petros.

- $\quad$ Fairy tale (8), "My mother's mother-in-law, (Свекърва на майка ми)". Title analysis: anthropocentric model, declarative, pronounced, affirmative, declarative, hyphenated phrase. 
INTERNATIONAL JOURNAL OF ACADEMIC RESEARCH IN BUSINESS AND SOCIAL SCIENCES

Vol. 9, No. 6, June, 2019, E-ISSN: 2222-6990 @ 2019 HRMARS

Grammatical analysis: Two nouns in a female signifier. Scenario: A very clever Petros and his kinship grades. Symbols and images: Folk wisdom, very clever Petros.

- $\quad$ Fairy Tale (9), "The fox and the vineyard, (лисщата и лозеmo)". Title analysis: animal model, declarative phrase. Grammatical analysis: a noun in a female signifier and a noun, in a negative signifier. Scenario: Greed is a bad fox adviser. Symbols and images: the animal and the plant.

Especially from the villages (Кавадарци, Битола) in Fyrom we collected the following:

- $\quad$ Fairy Tale (10), "The blind king and his son, (СЛЕПИОТ ЦАР И СИН)".

Title analysis: anthropocentric model, pronounced, affirmative, hyphenated, declarative phrase. Grammatical analysis: two nouns, an adjective gives a regular rating to one noun. Scenario: A prince trying to find a cure for his father, because of his superficiality, is trapped in a mountain. There he manages to marry the princess, to prove to the king his mistake and eventually, to become king. Symbols and images: royal axioms, relatives, apple, wise, fairies.

- $\quad$ Fairy Tale (11), "The devil teacher, (ЃАВОЛОт УчИТЕЛ)". Title analysis: anthropocentric model, verbal, affirmative, metaphorical phrase. Grammatical analysis: a noun in a male signifier, one in quote gives a rating to the noun. Scenario: A child using his mind manages to trick his teacher (devil) and secure a better future for him and his family. Symbols and images: The poor family, the devil, the smart young, the transformations.

- $\quad$ Fairy Tale (12), "The lady king ghoul, (ЦАРЕВA ḰEPKA - ЛAMJA)". Title analysis: anthropocentric and mythological mixed model, affirmative, metaphorical phrase. Grammatical analysis: a noun in a female signifier, a noun in singular. Scenario: King's desire to have a daughter leads him in co-operation with the devil. But the effects are terrible. The younger son who went away returns and finds the kingdom corrupted. His sister is now ghoul and tries to eat him too. But finally, he is saved by his faithful dogs. Symbols and images: king's desire, the nine siblings, the transformation, his struggle, the faithful dogs.

Especially from the villages (Guca , Београд, Нови Сад) in Serbia we collected the following:

- $\quad$ Fairy Tale (13), "The girl who was a bird, (Тицадјевојка)". Title analysis: anthropocentric and animal, mixed model, affirmative, hyphenative, metaphorical phrase. Grammatical analysis: a noun in a female signifier, a verb, a noun in a singular explanation of the noun, noun, verb and signify. Scenario: The king, disappointed by his failure to find a girl to marry and satisfy his father, is preparing to commit suicide. He is saved thanks to the intervention of an unknown who advises him how to achieve his purpose. So, he defeats the wicked witch and frees his waking wife and other enchanters from the spells. After many adventures they return to the king's house and marry. Symbols and images: royal axioms, kinship value of marriage, witches, bird.

- $\quad$ Fairy Tale (14), "The pig, the bear and the fox, (Међед, свиња и лисица)". Title analysis: animal model, pronounced, affirmative, hyphenated, declarative phrase. Grammatical analysis: three nouns one neutral, two females' nouns in singular. Scenario: Animals are associated and cultivate the land. But in the sharing, they wrongly at the fox. She wants to denounce them to the king. After a series of events the fox is justified. Symbols and images: The archetypal animal forms.

- $\quad$ Fairy Tale (15), "The devil and his disciple, (ЂАВО И ЊЕГОВ ШЕГРТ)". Title analysis: mythological anthropocentric model, pronounced, affirmative, hyphenated, metaphorical phrase. 
Grammatical analysis: two nouns in male signifier, interacting with each other. Scenario: A child using his mind manages to trick his teacher (devil) and secure a better future for him and his family. Repetition fairy-tale pattern with a small variation. Symbols and images: the poor family, the devil, the smart young, the transformations.

- $\quad$ Fairy Tale (16), "The riddles of the daughter, (МУДРИЦА ПРОШЕЛИЦА)".

Title analysis: anthropocentric model, pronounced, affirmative, hyphenated phrase.

Grammatical analysis: a noun in female signifier, a neutral to singular. Scenario: A young girl impresses the suitors with her riddles and her answers. Symbols and images: daughter's intelligence. - $\quad$ Fairy Tale (17), "House neither in the sky nor in the earth, (ЧАРДАК НИ НА НЕБУ НИ НА ЗЕМЉИ)". Title analysis: topographic model, pronounced, hyphenated, negative, metaphorical phrase. Grammatical analysis: two neutral nouns in singular, two negative links. Scenario: Despite the king's attempt to protect his daughter, the dragon kidnaps her. Her three brothers go to save her. But only the younger brother makes sacrifices and saves the girl. The other brothers from their jealousy leave him imprisoned and try to take advantage of. The younger, however, overthrows the situation and justice is restored. Symbols and images: royal axioms, kinship, heroism, dragon, vindication.

Roma-Ptolemaida (settlement):

- $\quad$ Fairy tale (18), "The life of a human". Title analysis: anthropocentric model, pronounced, affirmative, hyphenated phrase. Grammatical analysis: a noun in female signifier in singular with general possessive. Scenario: How a human managed to live a hundred years. Symbols and images: God, man.

Especially from the villages (Korçë, Tiranë) in Albania we collected the following:

- $\quad$ Fairy tale (19), "The Zana". Title analysis: anthropocentric model, pronounced, affirmative, hyphenated, declarative phrase. Grammatical analysis: a noun female signifier in singular. Scenario: The little sister is totally different from her two older sisters.

- $\quad$ All the mother's attention focuses on the two biggest sisters. The goodness of the little one causes the good witch to provide her with rare gifts. When the bigger ones try to imitate her, they fail and then try to hurt their sister. She finds shelter in the forest where she meets the prince and married him while the sisters are punished accordingly. Symbols and images: kinship, the good witch, value of kindness.

- $\quad$ Fairy tale (20), "Gishtoja". Title analysis: anthropocentric model, pronounced, affirmative, hyphenative, declarative phrase. Grammatical analysis: a noun male signifier in singular. Scenario: The adventures of Gishtoja and his brothers, children of a poor family. Their parents as they cannot feed them, trying to get rid of them. Because of the little one they survive. The little one because he is very smart, defeats the evil dragon and finds a way to make money and his family out of the stalemate. Symbols and images: kinship, value of intelligence, witchcraft, monster.

- $\quad$ Fairy Tale (21), "Beard blue, Mjekërkaltri". Title analysis: anthropocentric model connotation, verbal, affirmative, hyphenative phrase. Grammatical analysis: a noun neutral to singular, an adjective to singular gives rating to the subject. Scenario: A rich but revolting man wants to get married. He tries to charm two sisters but they are cautious. Finally, the younger woman agrees to marry him. After a long time, the husband leaves for business. Despite the ban, the wife enters the 
forbidden room. She discovers that he hides the previous women there, dead. The husband discovers the offense and attempts to kill her. She is saved from the interruption of her brothers. Symbols and images: kinship, ugliness, secret.

Especially from the village (Split) in Croatia we collected the following:

- $\quad$ Fairy Tale (22), "The little fairy, (MALA VILA)". Title analysis: anthropocentric model, pronounced, affirmative, hyphenated metaphorical phrase. Grammatical analysis: a noun female in singular, an adjective in singular gives a rating to the noun. Scenario: After the end of celebrating his adulthood, the young prince makes a walk in the forest. There he meets a fairy and she gives him her glove. Through this they communicate and then marry. When, however, after a while, the prince turns his gaze to another girl, the fairy begins to diminish until she disappears and the prince remains unhappy for the rest of his life. Symbols and images: prince axiom, marriage, fairy. Especially from the Vlachs village (Magarevo) we collected the following:

- $\quad$ Fairy Tale (23), "Why the sheep have a thick and furry tail". Title analysis: animal model, declarative questioning phrase. Grammatical analysis: a neutral noun in plural, two adjective female plural, rating to the noun. Scenario: The sheep save Christ who persecuted him and he blessed them and made them the animal of God. Symbols and images: the animal of God, the sheep.

Romania: Fairy tale (24), "The sun and the moon, (SOARLI SI LUNA)". Title analysis: cosmological model, metaphorical phrase. Grammatical analysis: two nouns, male and neutral in singular. Scenario: Like all siblings, the sun and the moon conflicted. The sun hit the moon so loud it broke its bile. Since then, the moon is yellow and never again met. Symbols and images: the sun, the moon.

- $\quad$ Fairy tale (25), "A smart vizier, (UN VIZIRU CU MINTI)". Title analysis: anthropocentric model, pronounced, affirmative, hyphenated, declarative phrase. Grammatical analysis: a noun male to singular, a singular adjective gives a rating to the noun. Scenario: The vizier of the Shah of Persia proved in a very smart way that his investment was risky and he was in danger of being poor. Symbols and images: axioms and other culture intelligence.

\section{The Results}

The common patterns in all the Balkan narratives refer to:

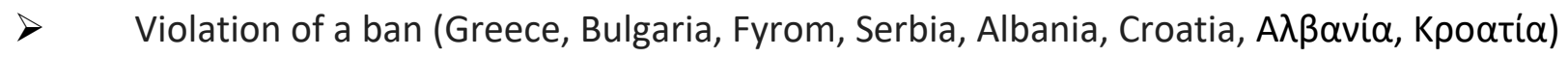

$>\quad$ The poor but smart young (Greece, Fyrom, Serbia, Albania)

$>\quad$ The young man who, after bravery, is justified (Greece, Bulgaria, Fyrom, Serbia, Albania)

$>\quad$ Animals that work like humans (Greece, Bulgaria, Fyrom, Serbia, Vlach fairy tale)

$>\quad$ Bad relatives, good young, usually the smallest one (Greece, Bulgaria, Fyrom, Serbia, Albania)

$>\quad$ King, princess, prince, they cause adventures with a happy ending (Bulgaria, Fyrom, Serbia, Albania, Croatia, Romania)

$>\quad$ Transformations (Greece, Bulgaria, Fyrom, Serbia, Croatia)

$>\quad$ The evil, dragons witches, wizard, good old-women (Greece, Bulgaria, Fyrom, Serbia, Albania, Croatia)

$>\quad$ The intelligence (Greece, Bulgaria, Fyrom, Serbia, Albania, Romania).

The axioms that have been found refer to:

\section{$>\quad$ King, Prince, Princess, Vizier.}


The animals that have been found refer to:

$>\quad$ Horse, Donkey, Fox, Bear, Dog, Sheep, Snake, Bird, Pig.

The Gender is used as: Female and male such as in the roles of

$\begin{array}{lll}\text { 1. } & \text { Wife } & \text { 1.Teaher } \\ \text { 2. } & \text { Young lady } & \text { 2. Kiliaftses-young man } \\ \text { 3. } & \text { Princess } & \text { 3. Shepherd } \\ \text { 4. } & \text { Daughter } & \text { 4.Clever Petros } \\ \text { 5. } & \text { Ghoul } & \text { 5.Prince } \\ \text { 6. } & \text { Witch } & \text { 6. Rich man } \\ \text { 7. } & \text { Mother } & \text { 7. Husband } \\ \text { 8. } & \text { Fairy } & \text { 8.Vizier. }\end{array}$

\section{Educational Suggestion - Balkan Countries and Fairy Tales}

According to Borrelli (1991), pedagogy needs to be restructured with a view to interculturalism, in order to overcome national borders and ideological ghettos with the ultimate goal of getting students to become aware of their prejudices, stereotypes and ideologies (in Govaris, 2001:83-84). The response to the reality of multicultural society is intercultural education, which will allow the exchange of views, the peaceful living of peoples and ideologies, the fruitful and creative coexistence of different cultures and the shaping of a common future. Intercultural education is not a complement or variety that simply enriches the knowledge of children of minority groups by facilitating their integration into the normal one-culture school, but is of a cross-reactive nature as it addresses all members of multicultural society, both institutional and individual. It looks forward to their sensitization so that mutual tolerance, understanding, recognition and acceptance (Markou,1995 at Sampani \& Markantonatou, 2006).

Migration and refugee flows are increasing and populations across countries are mixed. However, intercultural education does not only concern immigrants, it does not only take into account the origin parameter. What is mainly about intercultural education is the different people's culture. The educator, from pre-school age, is invited to respond to the needs of the new reality, to develop sensitization and social inclusion programs, with the main tool of fairy tales, as they are the main core of interest for preschool children.

The value of traditional fairy tales is multifaceted. It recreates children while promoting their cognitive development, opens paths for knowledge of themselves but also for the wider world that surrounds them (Norton, 2006:232, Bosma, 1992:1). The specific multicultural Fairy Tales, "help children to clarify their own values and concerns about appropriate behavior, and to develop concepts about the meanings of big ideas such as truth, courage and kindness": thus they become familiar with the major characteristics of fairy tales, they can compare and contrast different fairy tales, they can identify basic themes common in many fairy tales, they can explore roles of male and female characters, the can examine the varied portrayals of dragons and the use of kind animals in fairy tales. The aim is to use fairy tales to reinforce the writing of narratives, to strengthen reading comprehension skills through the use of fairy tales, to write traditional and fractured fairy tales, to study aspects of the culture from which each fairy tale derives, to locate the country from which each 
fairy tale originates on a world map and note its basic features, to learn how the people of that country dressed and lived in that time period.

The child in pre-school age is not moved by the morality of fairy tales, but by their heroes who personalize it as the hero is the most attractive for the child (Kontakos, 2003: 189-190). A methodological approach could be dramatization and music-kinetics. Such a proposal aims at the readiness and ability of children with the ultimate goal, interest and awareness of diversity. Incentive in a preschool environment can be a child with an origin from any Balkan country, which every day in the classroom has difficulty integrating with the rest of the Greek-speaking child. The teacher discusses with the children and decides together the next day to narrate his/her favorite fairy tale in his/her home language.

The fairytale can be presented by the pedagogue with a pictogram or accompanied by music. Then the children in cooperation with the teacher decide to dramatize the fairy tale and to represent roles in the classroom. This activity can also be accomplished by accompanying narration from the computer so that children feel more familiar with the unknowns so far. Respective movegames of another country or culture can be presented to the classroom and children to become the protagonists. In this way, child can express more interest for even more cultures and create a project where the children themselves will have the title: "Knowing the World ...".

In the university, students using this researching material, could learn that folk tales follow a pattern, and they will attempt to analyze a story to discover its pattern. In particular the multicultural fairy tales share common themes and address such larger questions as these for young people to consider: What is truth and why should anyone fight for it? What role does unselfishness play in our relationships with others? Can courage take many different forms? Is it urgent that justice be served? The objectives are: Students will be able to find patterns in a text. Students will be able to use the text of a folk tale to increase their skills in reasoning through the identification of analogies. Students will be able to construct their own folk tale based on elements of their own culture.

We also could explain to students that folk tales often has a structured pattern underlying their story line. Being able to uncover the pattern, they could increase their ability to think about and analyze the story at higher levels, to explain that there is a pattern within the selected folk tale that doesn't have anything to do with the literal elements of the story. Thus we do claim that these fairy tales help children to project, fostering their development, offering knowledge of life from the inside, help to dispel fears, corresponding to the child's thinking and experience as Bruno had already suggested (1989).

\section{References}

Borrelli, M. (1991). "Intercultural pedagogy: Foundations and principles" in D. Buttjes and M. Byram (Eds.), Mediating languages and cultures: Towards an intercultural theory of foreign language education (275- 286). Clevedon: Multilingual Matters.

Bosma, B. (1992). Fairy tales, fables, legends and myths. Using folk literature in your classroom. New York: Teachers College Press.

Bruno, B. (1989). The uses of enchantment: the meaning and importance of fairy tales. New York: Vintage Books. 
INTERNATIONAL JOURNAL OF ACADEMIC RESEARCH IN BUSINESS AND SOCIAL SCIENCES

Vol. 9, No. 6, June, 2019, E-ISSN: 2222-6990 (C) 2019 HRMARS

Cenoz, J. (2009). Towards multilingual education: Basque educational research in international perspective. Clevedon: Multilingual Matters.

Colovic, I. (2003). «Les pretres de la langue. Poésie, nation et politique en Serbie», «Terrain», No 41. Nanter.

Darn, S. (2009). Teaching other subjects through English, cross-curricular resources for young learners: Uncovering CLIL. Book review. ELT J, 63(3), 275-277.

Eco, U. (1985). Lector in fabula. Paris: Grasset.

Eco, U. (1988). Sémiotique et philosophie du langage. Paris: PUF.

European Commission. (2007). Final report: High level group on multilingualism. Luxembourg: European Communities. p.6.

Govaris, C. (2001). Introduction to Intercultural Education, Ed. Atrapos, Athens.

Katsanis, N., \& Dinas, K. (1990). Grammar of the Common Koutsovlachik. Thessaloniki: Archive of Koutsovlachikon Studies 1.

Koukoudis, A. (2003). The Vlachs : Metropolis and Diaspora. Thessaloniki: Zitros.

Kontakos, A. (2003). Mithi kai ekpedefsi: Protasis gia mia pedagogiki tu mithu. Athina: Atrapos (in greek).

Norton, D. (2006). Mesa apo ta matia enos paidiou. Eisagogi sthn paidikh logotehnia. Thessaloniki: Epikentro.

Peirce, Charles S. (1931-1935). Collected Papers of Charles Sanders Peirce (Volumes I-VI, ed. by Charles Hartshorne and Paul Weiss, Volumes VII-VIII, ed. by Arthur W. Burks, 1958). Cambridge, Mass.: Harvard UP.

Psaltou-Joycey, A., Agathopoulou, E., \& Mattheoudakis, M. edit. (2014). Cross-Curricular Approaches to Language Education. Cambridge Scholars Publishing.

Sampani, S., \& Markantonatou, A. (2006). Diapolitismikotita. Didaktikes prosegisis sto Dimotiko Sholio. Athina: Taxideftis (in greek).

Thomas, P. L. (2002-2003). «Le serbo-croate (bosniaque, croate, monténégrin, serbe): de l'étude d' une langue à l'identité des langues», Revue des études slaves. Paris.

Todorov , T. (1969). Grammaire du Dicameron. The Hague: Mouton.

Tomashevsky, B. (1931). Thematology. in his Teoriya literatury. Leningrad.

Tsotsos, C. (1996). The dictatorship changes from North Epirus to Western Macedonia (Volume V). Kozani: Western-Macedonian Letters. 